\title{
Application of lead time analysis as a method in EU co-funded mid-term programme evaluations in 2007-2013: the case of Bulgaria and Malta
}

\author{
Balázs Mezősi \\ National Development Consulting Zrt., Budapest \\ balazs.mezosi@ndczrt.hu
}

SUMMARY

\begin{abstract}
Mid-term evaluation of grant programmes always aims to assess the efficiency of programme implementation. An important aspect of assessing efficiency is the lead times of the application mechanisms. A detailed and objective analysis of lead times may set the scenes for an in-depth evaluation of the relevant entities in the application process in terms of capacity, competences or the process itself. The Bulgarian regional operational programme (OPRD) and the Maltese ESF operational programme (OPII) mid-term evaluations offer an opportunity to see application of this method on the ground with a view on results and comparisons. This article attempts to provide an overview on lead time analysis, being a simple but powerful tool for evaluation with great benefits and also great potential pitfalls in terms of use and interpretation.
\end{abstract}

Keywords: lead time, program evaluation, mid-term evaluation

ÖSSZEFOGLALÁS

A támogatási programok közbenső értékelésének egyik alapvető területe a program hatékonyságának értékelése. A hatékonyság megitélésének fontos szempontja a pályázati rendszer átfutási ideinek vizsgálata. Az átfutási idők részletes, objektiv elemzésének eredményei lehetövé teszik a rendszer szereplöinek mélyebb - kapacitás, kompetencia, folyamatszervezési szempontú - értékelését. A bolgár regionális operatív program (OPRD) és a máltai ESZA finanszírozású operativ program (OPII) közbenső értékelése lehetőséget teremt e módszer gyakorlati, eredmény fókuszú ismeretésére. E cikk egy átfogó képet kíván nyújtani az átfutási idők vizsgálatáról, mely egy egyszerü, de jól alkalmazható értékelési eszköz, számos elönnyel, és jelentős buktatókkal, föként az alkalmazás és az eredmények értelmezése terén.

Kulcsszavak: átfutási idö, programértékelés, közbenső értékelés

\section{INTRODUCTION}

Lead time analysis is a basic but powerful tool for measuring an important aspect of efficiency in a grant system. Lead time analysis is used to objectively judge how much time is spent in between the relevant stages of the entire application and implementation process. Relevant in this context is a result of pre-definition: it depends on the scope and depth of the analysis. Most often, however, the subject of the assessment is either the application process, or the implementation process, or both. As a first step to starting the assessment, the relevant stages and corresponding data has to be defined (e.g. which stages are required by the analysis).

The potential outputs of a lead time analysis are twofold: first, the assessment may shed light on where the bottlenecks in the process are, and what their severity is (internal assessment) and second, output figures can be compared across the institutional system or other benchmark data in order to identify which entities require more time for a certain process and what is the reason for that (e.g. capacity shortage, capability or competence issues).

\section{PROJECT SELECTION PROCESS}

As a first step to understanding the context, the grant allocation process (e.g. an application process or other type of project selection and implementation process) has to be clearly defined. In order to demonstrate the use of the lead time assessment method, a standard grant application process will be used, consisting of a three-level project selection mechanism including an administrative, an eligibility and a technical assessment on the application submitted. It is presumed that if an application passes through all three levels, then it is approved, a grant contract is signed, then implementation and corresponding payment can be initiated to the beneficiary.

A standard application process for demonstrating purposes includes seven major steps from submission of application up to payment of the grant (Figure 1). Please note that in some of the Member States the three-stage (administrative, eligibility and technical) application assessment process is reduced to two (see the Bulgarian example later in this article) or even one in practice by integrating one stage into another.

Figure 1: A standard project selection (application) process using a three-stage selection system

$\begin{gathered}\text { Submission } \\ \text { of application }\end{gathered}>\begin{gathered}\text { Administrative } \\ \text { assessment }\end{gathered}>\begin{gathered}\text { Eligibility } \\ \text { assessment }\end{gathered}>\begin{gathered}\text { Technical } \\ \text { assessment }\end{gathered}>$ Approval $>$ Contracting $>$ Payment $>>$




\section{METHOD}

The purpose of the lead time assessment is to create a sound and objective basis for the evaluation of efficiency of the grant allocation and implementation process. In this context, lead times can be defined as time spent between any two relevant stages of the grant process. This objective information then can be used to compare with other figures and to explore reasons behind the facts.

The execution of the method requires two steps: 1) data collection and verification and 2) analysis.

Data collection regards project application data available in the monitoring and information system. It is important to highlight, that lead time analysis may use project samples, and however, it is a method that prefers robust and complete data set to be available for the assessment. Data should be verified by the assessment of the monitoring and information system (data structures, methodologies used such as data conversion methods, and data completeness), which is to be coupled with a small sample for pre-testing (pilot).

Table 1 below shows an example of a data input table required for the assessment.
The lead time analysis might concentrate on a number of indicators for each project, but at least on:

- application assessment time: days spent from submission of the project application up till technical assessment,

- application approval time: days spent from technical assessment to contracting,

- contracting time: from submission to contracting (i.e. the sum of the previous two indicators).

The above figures for each projects are to be aggregated by the organisation responsible for the processing of project applications and supporting and monitoring project implementation tasks. The absolute values of these aggregates enable assessment on three levels: 1) assessment of the figures themselves, 2) comparison with other organisation of the fund management institutional system, and 3) comparison with similar organisations in other member states.

The next two examples show how in Bulgaria (mid-term evaluation of the 2007-2013 Regional Operational Programme) and Malta (mid-term evaluation of the 2007-2013 European Social Fund based OPII Operational Programme) used the lead time assessment and what results its application could bring.

Lead time analysis standard data collection sheet

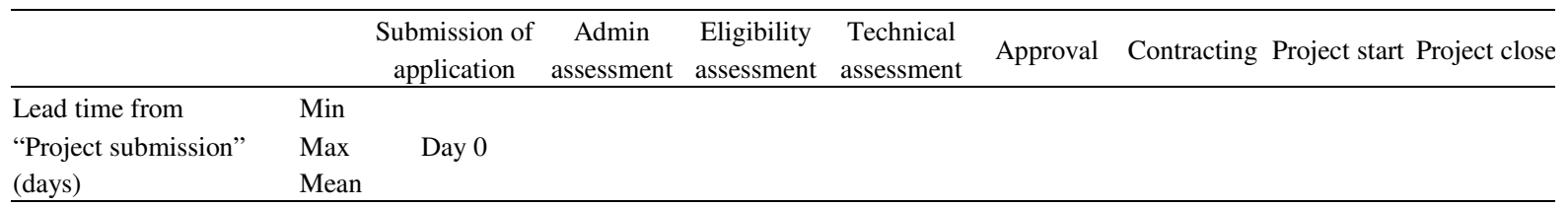

\section{INTERNATIONAL EXAMPLE 1-OPRD MID-TERM EVALUATION, BULGARIA}

The lead time analysis of the OPRD focused on the project selection process from submission of the application, through technical (also including admin and financial) check to approval and then contracting.

These stages represent the relevant points of the assessment. The figures drawn as a result set the scene for the evaluation of reasons behind the durations that were longer than expected or adequate. Part of the assessment concentrated on the identification of bottlenecks in the process, and also the comparison of figures with national regulations on provisions governing the deadlines for the implementation system.

The assessment found that the length of the total lead times largely depended on the project selection methods. Schemes with a rolling submission procedure had longer average total lead time (127 days), while projects with a fixed deadline had a slightly shorter total lead time (120 days). The total lead time from registration of applications to contract signing took 118 days for OPRD projects, according to the analysis. Table 2 shows the operations of the OPRD along with the relevant lead time figures between the identified stages of the application process.

As the Table 2 above shows the applications of Operation 1.1 and Operation 3.1 had to go through the longest process, with Operation 1.1 being the most popular Operation, a logical reason might be the high number of applications which caused heavy workload for the MA to process.

The TA projects (Operation 5) have been processed very quickly which reflects the special character of TA. Operation 3.3. was also very quick thanks to the low number of projects processed.

Placing the overall lead time result to an international context highlights the fact that the Bulgarian OPRD total lead time result at the end of 2010 was somewhere in between the corresponding value of the Romanian Regional OP (292 days) days and the seven Hungarian Regional OPs' average of 63 days.

\section{From registration to technical and financial check}

The average lead time from registration to the technical and financial check was 89 days. In the case of Operation 1.1 this process took significantly longer (125 days), while in Operation 3.3 shorter, 38 days, respectively (Table 3$)$.

The deviation of lead times of Operation 2.1 applications was the most spectacular: it varied from 13 to 271 days to reach the technical and financial check from the registration. The case of Operation 1.1 was also similar, with lead time ranging from 51 to 262 days. 
Summary table of lead times in OPRD, Bulgaria evaluation

\begin{tabular}{lcccc}
\hline Operation & Contracted projects & $\begin{array}{c}\text { From registration to technical and } \\
\text { financial check }\end{array}$ & $\begin{array}{c}\text { From technical and financial } \\
\text { check to approval }\end{array}$ & $\begin{array}{c}\text { Total lead time: from } \\
\text { registration to contracting }\end{array}$ \\
\hline 1.1 & 133 & 125 & 10 & 139 \\
1.4 & 70 & 70 & 11 & 120 \\
2.1 & 58 & 93 & 16 & 120 \\
3.1 & 10 & 51 & 7 & 61 \\
3.3 & 9 & 38 & 15 & 111 \\
4.1 & 108 & 74 & 19 & 125 \\
4.2 & 55 & 71 & 16 & 58 \\
5 (TA total) & 43 & 38 & 13 & 118 \\
Total & 486 & 89 & & 5 \\
\hline
\end{tabular}

Source: OPRD mid-term evaluation (2011) (based on UMIS dataset, 31.12.2010)

Table 3

Lead time analysis from registration to technical and financial check results OPRD, Bulgaria evaluation

\begin{tabular}{lcrrc}
\hline Operation & Average & Min & Max & Deviance \\
\hline 1.1 & 125 & 51 & 262 & 42.3 \\
1.4 & 70 & 1 & 126 & 29.8 \\
2.1 & 93 & 13 & 271 & 48.3 \\
3.1 & 51 & 36 & 99 & 22.2 \\
3.3 & 38 & 27 & 43 & 8.0 \\
4.1 & 74 & 32 & 124 & 17.2 \\
4.2 & 71 & 71 & 80 & 1.0 \\
5 (TA & 38 & 1 & 141 & 32.6 \\
Total & 89 & 1 & 271 & 43.3 \\
\hline
\end{tabular}

Source: OPRD mid-term evaluation (2011) (based on UMIS dataset, 31.12.2010)

Table 4 shows the difference of pattern when separating applications of the OPRD with rolling submission and set deadline procedures.

In Table 4 above the first table shows the rolling submission procedure, where no deadline has been set and the second one shows the procedures with a fixed deadline. There are huge differences between the two project selection methods. At rolling selection procedure the average lead time is significantly higher (112 days), than the procedures with a certain deadline, where the average lead time is 71 days, which is low compared to the overall average lead time from registration to technical check ( 89 days). At the set deadline procedures the deviance has also decreased to 29.3 days. So in overall, the project selection with a set deadline lead to a significantly lower lead time (from registration to technical and financial check) and also to lower deviance.

\section{From technical and financial check to approval}

The other relevant assessment period of the application system is the time spent between a positive recommendation on the provision of grant to a beneficiary by the intermediary body and the official decision of the management authority. This is a rather administrative action indicating the smoothness of cooperation between the actors of the management and implementation system.
Table 4

Lead time analysis rolling and set deadline procedures from registration to technical and financial check results OPRD, Bulgaria evaluation

\begin{tabular}{|c|c|c|c|c|}
\hline Operations & Average & Min & $\operatorname{Max}$ & Deviance \\
\hline \multicolumn{5}{|c|}{ Rolling submission procedures } \\
\hline 1.1 & 140 & 65 & 208 & 28.4 \\
\hline 1.4 & - & - & - & - \\
\hline 2.1 & 100 & 27 & 168 & 50.1 \\
\hline 3.1 & - & - & - & - \\
\hline 3.3 & - & - & - & - \\
\hline 4.1 & 75 & 32 & 108 & 18.5 \\
\hline 4.2 & - & - & - & - \\
\hline 5 (TA total) & - & - & - & - \\
\hline Total & 112 & 27 & 208 & 42.3 \\
\hline \multicolumn{5}{|c|}{ Set deadlines procedures } \\
\hline$\overline{1.1}$ & 84 & 51 & 262 & 48.3 \\
\hline 1.4 & 72 & 25 & 126 & 29.0 \\
\hline 2.1 & - & - & - & - \\
\hline 3.1 & 49 & 36 & 87 & 21.5 \\
\hline 3.3 & - & - & - & - \\
\hline 4.1 & 73 & 46 & 124 & 14.9 \\
\hline 4.2 & 71 & 71 & 80 & 1.0 \\
\hline 5 (TA total) & - & - & - & - \\
\hline Total & 71 & 25 & 262 & 29.3 \\
\hline
\end{tabular}

Source: OPRD mid-term evaluation (2011) (based on UMIS dataset, $31.12 .2010)$

With an average of 13 days the process from technical and financial check to approval took the shortest time among the lead times in between the relevant stages of the application process. This average figure varies between 7 (Operation 3.3) to 19 (Operation 4.2) days to approve the checked applications (Table 5).

\section{Total lead time: from registration to contracting}

A summary of the individual results of the lead times in between single statuses (Figure 1) showed that the average total lead time was 118 days with OPRD applications. Operation 3.1 leads the rank in terms of average lead time with a figure of 142 days. Operation 3.3 has the shortest average time (except TA) that passed 
from the registration of application to contracting which took 51 days. The shortest individual lead time belongs to Operation 1.4, with only 1 day (Table 6).

Table 5

Lead time analysis from technical and financial check to approval summary of results OPRD, Bulgaria evaluation

\begin{tabular}{lcrcc}
\hline \multicolumn{1}{c}{ Operation } & Average & Min & Max & Deviance \\
\hline 1.1 & 10 & 2 & 17 & 5.3 \\
1.4 & 11 & 1 & 18 & 4.3 \\
2.1 & 16 & 2 & 33 & 11.8 \\
3.1 & 14 & 10 & 33 & 3.2 \\
3.3 & 7 & 5 & 10 & 2.5 \\
4.1 & 15 & 8 & 26 & 5.7 \\
4.2 & 19 & 19 & 19 & 0.0 \\
5 (TA total) & 16 & 1 & 39 & 15.4 \\
Total & 13 & 1 & 39 & 7.3 \\
\hline
\end{tabular}

Source: OPRD mid-term evaluation (2011) (based on UMIS dataset, 31.12.2010)

Lead time analysis from registration to contracting summary of results OPRD, Bulgaria evaluation

\begin{tabular}{lcrcc}
\hline \multicolumn{1}{c}{ Operation } & Average & Min & Max & Deviance \\
\hline 1.1 & 139 & 81 & 283 & 42.8 \\
1.4 & 120 & 1 & 211 & 53.4 \\
2.1 & 120 & 30 & 481 & 62.8 \\
3.1 & 142 & 97 & 149 & 16.1 \\
3.3 & 61 & 51 & 81 & 15.0 \\
4.1 & 111 & 62 & 548 & 64.4 \\
4.2 & 125 & 110 & 428 & 62.9 \\
5 (TA total) & 58 & 2 & 182 & 41.8 \\
Total & 118 & 1 & 548 & 58.4 \\
\hline
\end{tabular}

Source: OPRD mid-term evaluation (2011) (based on UMIS dataset, 31.12.2010)

INTERNATIONAL EXAMPLE 2-OPII MID-TERM EVALUATION, MALTA

The evaluation used two lead time analyses, one for the application process and another for the invoice payment process for OPII, which was the 2007-2013 Operational Programme governing all European Social
Fund related interventions in Malta. For easy comparison with Bulgarian figures, only the application process lead time assessment is presented in this section. Please note that the Bulgarian case counts in days, while the Maltese example contains a more advanced view by calculating in working days.

The analysis was carried out in order to provide an insight into the efficiency of the application process at the Managing Authority and the Intermediary Body, in respect of OP II related activities. The data included a series of tracking dates spanning the entire application process, as applicable, for the selected and non-selected applications.

The tracking dates included:

- application submission date,

- eligibility check date,

- evaluation result date,

- for selected projects:

- letter of offer date,

- Grant Agreement date;

- for non-selected applications:

- letter of rejection/non-selection date.

The data was then analysed to arrive at the number of working days (taking into consideration the local calendar of national and public holidays) elapsed between:

- each of pair of sequential events as described above,

- the cumulative days elapsed from submission of application to the three key events as follows:

- from submission to letter of offer (for selected applications),

- from submission to Grant Agreement (for selected applications),

- from submission to letter of rejects/non-selection (for non-selected applications).

It is important to note that:

- applications that were still under evaluation as at cut-off date were not included as the detailed tracking data was not available,

- event pairs completed on the same date were treated as equivalent to 0 working days.

The lead time analysis shown in Figure 2 and Figure 3 below and reflect the analysis in respect of the application process at the MA and the relevant IB, by the respective call for applications and/or aid scheme as applicable.

Figure 2: Lead time analysis of the application process by calls OPII, Malta mid-term evaluation

\begin{tabular}{|c|c|c|c|c|c|c|c|c|}
\hline \multicolumn{9}{|l|}{ Managing Authority } \\
\hline & \multirow{2}{*}{$\begin{array}{r}\text { No. of } \\
\text { applications }\end{array}$} & \multirow{2}{*}{$\begin{array}{r}\text { Submission } \\
\text { to Eligibility } \\
\text { Check }\end{array}$} & \multirow{2}{*}{$\begin{array}{r}\text { Eligibility } \\
\text { Check to } \\
\text { Evaluation } \\
\text { Result }\end{array}$} & \multicolumn{2}{|c|}{$\begin{array}{l}\text { Evaluation } \\
\text { Result to Letter of } \\
\text { Letter of Offer to Grant }\end{array}$} & \multirow{2}{*}{$\begin{array}{l}\text { Submission to } \\
\text { Letter of Offer }\end{array}$} & \multicolumn{2}{|c|}{$\begin{array}{l}\text { Submission to Submission } \\
\text { Grant to Rejection }\end{array}$} \\
\hline & & & & Offer & Agreement & & Agreement & letter \\
\hline \multicolumn{9}{|l|}{ ESF (By Call) } \\
\hline Call 1 - OPII - ESF & 16 & 68.1 & 56.0 & 72.5 & 251.7 & 187.3 & 412.7 & 112.0 \\
\hline Call 2 - OP\|I - ESF & 5 & 115.6 & 33.0 & 9.0 & No data & 148.0 & No data & 141.5 \\
\hline Call 3 - OP\|l - ESF & 37 & 102.2 & 28.3 & 50.0 & 277.5 & 169.3 & 449.7 & 137.4 \\
\hline Call 4 - OPII - ESF & 6 & 125.7 & 45.7 & 56.7 & No data & 228.0 & No data & 168.0 \\
\hline Call 5 - OP\|l - ESF & 28 & 157.8 & 54.4 & 36.0 & 122.8 & 245.3 & 327.0 & 178.4 \\
\hline Total No. of Applications & 92 & & & & & & & \\
\hline Overall Average & & 115.5 & 39.2 & 46.0 & 230.2 & 193.7 & 409.4 & 147.0 \\
\hline
\end{tabular}

Source: PPCD (2011) 
Figure 3: Lead time analysis of the application process by schemes OPII, Malta mid-term evaluation

\begin{tabular}{|c|c|c|c|c|c|c|c|c|}
\hline \multicolumn{9}{|l|}{ Intermediate Body } \\
\hline Aid Scheme & $\begin{array}{r}\text { No. of } \\
\text { applications }\end{array}$ & $\begin{array}{r}\text { Submission } \\
\text { to Eigibility } \\
\text { Check }\end{array}$ & $\begin{array}{r}\text { Elgibility } \\
\text { Check to } \\
\text { Evaluation } \\
\text { Result }\end{array}$ & $\begin{array}{r}\text { Evaluation } \\
\text { Result to Letter } \\
\text { of Offer }\end{array}$ & $\begin{array}{r}\text { Letter of } \\
\text { Offer to } \\
\text { Grant } \\
\text { Agreement }\end{array}$ & $\begin{array}{l}\text { Submission to } \\
\text { Letter of Offer }\end{array}$ & $\begin{array}{r}\text { Submission } \\
\text { to Grant } \\
\text { Agreement }\end{array}$ & $\begin{array}{r}\text { Submission } \\
\text { to Rejection } \\
\text { letter }\end{array}$ \\
\hline EAP & $1,047.0$ & 12.8 & - & 4.1 & 5.5 & 14.8 & 19.6 & 16.1 \\
\hline TAF & $1,084.0$ & 22.3 & 32.6 & 8.8 & 12.5 & 25.0 & 51.5 & 65.2 \\
\hline Total No. of Appl. & $2,131.0$ & & & & & & & \\
\hline Overall average & & 17.3 & 16.6 & 5.7 & 8.2 & 19.9 & 35.9 & 40.8 \\
\hline
\end{tabular}

Source: PPCD (2011)

The entire process in the case of Malta took an average of 193.7 days (Operation level means min: 148 days, max 245.3 days) for the Managing Authority to accomplish on average in between submission of an application and the letter of offer stage (very similar to the approval stage in the Bulgarian context). Deviances were great in between the Operations. As Figure 2 clearly shows, it was the submission to eligibility check stage that was clearly responsible for at least half of the lead times in the process with an average value of 116.6 days (Operation level means ranging from min 68.1 days to max: 157.8 days). However, in the case of interventions, where it was the Intermediary Body processing the applications (Figure 3), the process was much shorter: 19.9 days on average (min: 14.8, max: 25 days)

For a quick comparison with Bulgarian figures, there are many aspects that makes this OP different: there are fewer number of projects, the character of purely ESF interventions of OPII is different from the generally ERDF based regional development interventions of OPRD. However, the figures show an almost double value in the case of Malta which also promote the necessity to evaluate the reasons behind the facts.

\section{CONCLUSIONS}

Lead time analysis enables objective assessment of an important facet of implementation system efficiency.

The main advantages of the method are the following:

- The method is objective, promotes the establishment of a solid, evidence-based foundation for the further use of qualitative techniques (such as interviews of consultations for revealing the potential factors behind the figures calculated).

- The method uses monitoring data that is compulsory for each Member State to collect. Therefore it is unlikely that the assessment cannot be carried out as a result of lack of information of ability to access data. However, data clarity and completeness issues might arise.

- The method is flexible in the sense that the scope can be tailored to the length and specifics of the implementation system (e.g. number of processing stages) and the requirements of the evaluation.

- The figures calculated can be further used for other analyses, for instance to project related absorption risk assessment (if a project approaches $\mathrm{n}+2$ deadlines).
- The calculation of figures can also be easily automatized and integrated into a monitoring system for providing real-time reporting.

The most important limitations of the method are:

- Lead time figures calculated have to be interpreted with caution. The characteristic of the application handled by organisation may be significantly different. For instance, organisations handling small-scale mass applications for small and medium enterprise equipment procurements will presumably have lower lead times than those organisations which manage only a few but large infrastructure development projects. Therefore programme features such as call complexity, potential project size, preparatory and regulatory requirements, potential number of applicants have to be considered along with the figures when making comparisons and setting up hypotheses.

- In order to enable international comparisons, the stages of the application pipeline under assessment have to be in line with those to be compared to.

- Not only the absolute values and the means, but also the deviation of lead time figures carry important information for evaluation. Considerable deviation reflects the unbalanced operation of the organisation that might be the result of inadequate call definition, issues with scheduling or peak time capacity management considerations.

- It is important to note that when formulating evaluation findings, there is always at least three stakeholders to attribute the objective figures to: 1) the regulator 2 ) the implementing bodies (MA and IB(s), and 3 ) the applicants. Please note that issues on the applicant side should usually be handled through interventions in the operations of the regulator and the implementing bodies.

- Lead times generally vary based on the timing of the assessment. When starting a programme, the learning curve effect hinders operations on both the beneficiary and implementation system side. In later programme stages figures tend to converge to the real values, assuming that call portfolio and call conditions are rather stable.

- It is a common evaluation mistake that this method is only used to provide a stock indicator at the cut-off date for the evaluations („now”). In order to learn more about the learning capacity and adoptability of the implementation system, a dynamic assessment (,up till now”) can also be conducted. 


\section{REFERENCES}

Mid-term evaluation of OPII Malta (2011): Planning \& Priorities Coordination Department (PPCD). Malta.
Mid-term evaluation of Operational Programme Regional Development (OPRD) 2007-2013 (2011): Ministry of regional development and public works. Bulgaria. 